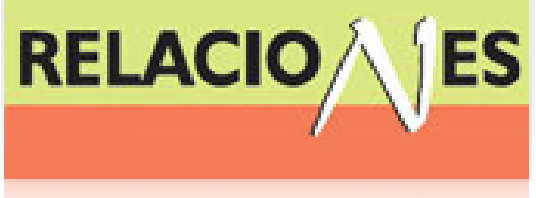

Relaciones. Estudios de historia y sociedad ISSN: 0185-3929

relacion@colmich.edu.mx

El Colegio de Michoacán, A.C

México

Ramírez Barreto, Ana Cristina

ERÉNDIRAS DE LEYENDA Y CARNE Y HUESO

Relaciones. Estudios de historia y sociedad, vol. XXXI, núm. 123, 2010, pp. 85-118

El Colegio de Michoacán, A.C

Zamora, México

Disponible en: http://www.redalyc.org/articulo.oa?id=13715893004

- Cómo citar el artículo

- Número completo

- Más información del artículo

- Página de la revista en redalyc.org

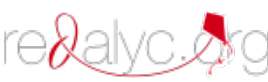

Sistema de Información Científica

Red de Revistas Científicas de América Latina, el Caribe, España y Portugal

Proyecto académico sin fines de lucro, desarrollado bajo la iniciativa de acceso abierto 


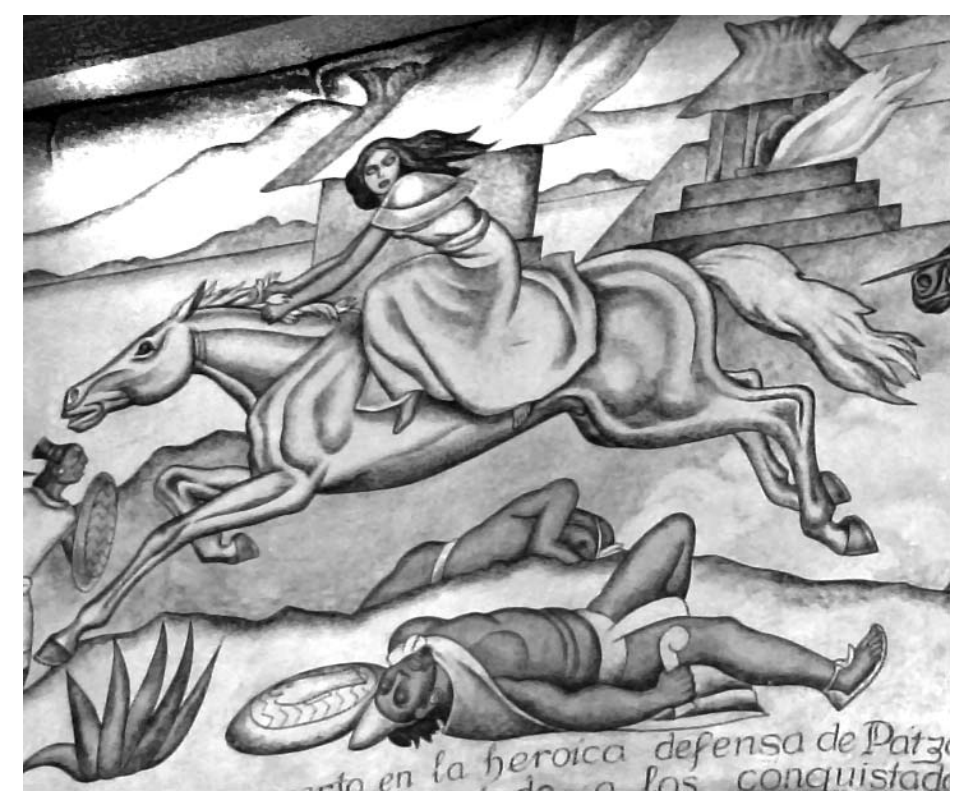

SECCIÓN Z EMÁtICA 


\title{
ERÉNDIRAS \\ DE LEYENDA Y CARNE Y HUESO
}

\author{
Ana Cristina Ramírez Barreto \\ Universidad Michoacana de San Nicolás de Hidalgo
}

Eréndira es una legendaria mujer purépecha que resistió a la conquista española aprendiendo a montar a caballo. También es un nombre personal, femenino, bastante común en Michoacán (México). Este trabajo da a conocer la leyenda y sus elementos, reflexiona sobre la importancia de este nombre personal ligado al auge de los cardenismos y expone los resultados de la búsqueda de las Eréndiras de carne y hueso.

(Eréndira, Eduardo Ruiz, Cárdenas, antropónimo)

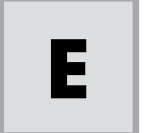

1 presente trabajo incorpora los resultados de la última etapa de investigación del proyecto "Eréndira, la leyenda tras el nombre" . ${ }^{1}$ La investigación documental arrojó que la leyenda de Eréndira fue escrita -y muy probablemente también inventada- por Eduardo Ruiz (1839-1902), abogado michoacano, historiador, novelista y guerrillero liberal (Guerra contra la Intervención

\footnotetext{
*ana_rb@yahoo.com

${ }^{1}$ Proyecto inscrito en el Programa de Mejoramiento al Profesorado (PROMEP, SEP) durante 2006 y 2007; contó con la participación de Mayra Gabriela Álvarez y Jaime Vieyra. Gloria Cáceres realizó la investigación en el Registro Civil de Uruapan y entrevistas. Agradezco al director del Registro Civil de Michoacán y al Ing. Antonio Lemus las facilidades para esta investigación. Especial agradecimiento para las Eréndiras entrevistadas, Néstor Dimas Huacuz y Juan Roberto Mora Cattlet. Versiones previas y parciales del mismo fueron presentadas en IV Congreso Internacional de historia de mujeres y género en México, El Colegio de Michoacán, Zamora, Mich., y Latin American Studies Association, Montréal, Canada, ambos en 2007. Agradezco los comentarios de Gloria Cáceres, Eréndira Anguiano, Eréndira de la Peña, Guadalupe Trejo, Adán Pando y de dos revisores de Relaciones. No habría sido posible concluir el proyecto sin la estancia sabática CONACyT 2009-2010, en la Universidad de California, Santa Cruz.
} 
Francesa). Ruiz noveló un documento histórico del XVI (La Relación de Michoacán o Códice Escorial). Ruiz ubica a Eréndira en el episodio de la llegada de los conquistadores españoles a territorio michoacano (1522). "Eréndira" es un relato de violencia, valentía, amor, traición y encuentro intercultural. Eréndira fue una mujer purépecha que se apropió de un caballo perdido por una avanzada de conquistadores españoles, aprendió a montarlo, resistió a la conquista durante un tiempo y luego ayudó a la evangelización de su gente.

Si bien Eduardo Ruiz no era un escritor desconocido en su tiempo y fue bien acogido ${ }^{2}$ su libro Michoacán, paisajes, tradiciones y leyendas (en cuyo segundo volumen aparece el relato "Eréndira"), no se le menciona ni una sola vez en los varios recuentos de la literatura nacionalista e indigenista en México. Más que referirnos a un boom literario, ocurrió con Eduardo Ruiz un boom político: el general Lázaro Cárdenas del Río, quizá el más grande estadista de México en el siglo xx, admiró la leyenda de Eréndira y solicitó a varios pintores de la segunda ola del muralismo mexicano (Fermín Revueltas, Roberto Cueva del Río, Juan O'Gorman) que pintaran la escena de Eréndira a caballo en sitios privados, los cuales devinieron públicos y didácticos cuando los donó para instituciones educativas.

Hacia mediados de los años treinta encontramos el nombre ya no sólo en la leyenda de Ruiz, fincas de Cárdenas y varios negocios que reivindicaban su tradicionalismo (como la Nevería Eréndira, en Pátzcuaro), sino también como antropónimo, nombrando a niñas nacidas en el seno de familias michoacanas que participaban en la vida política de la época. En estas "décadas cardenistas" (1930-1940) vemos que a más y más niñas se les impuso el nombre de Eréndira; y en más y más ocasiones en familias que no hablan purépecha, pero que sí estaban orgullosas del pasado indígena -posiblemente también del presente-. Atendiendo al antropónimo como un marcador de cambio cultural y posición política, es posible revelar tonos nacionalistas, populistas, vanguardistas en términos de cultura general, literaria y profesional. En el siglo xx se di-

\footnotetext{
${ }^{2}$ El primer volumen de Michoacán, paisajes, tradiciones y leyendas se publicó en 1891. El libro se agotó pronto, según cuenta el propio autor en el prólogo al segundo volumen (1900). Es posible encontrarlo en algunas bibliotecas públicas y casas particulares de personas interesadas en la historia de Michoacán, como bien observa uno de los revisores de este trabajo.
} 
funde el gusto por un relato referido a un momento crítico de la historia de este territorio, la llegada de los españoles y sus armas de guerra, en sí mismo previo a la idea de "una nación mexicana", pero de referencia obligada para el uso político de la historia. Las claves que destacan en este relato, como veremos más adelante con detalle, muestran la solución literaria al drama de la conquista, los conflictos internos en la sociedad nativa y la coexistencia con extranjeros.

El presente trabajo hace un recorrido general partiendo del relato de Eduardo Ruiz; las representaciones plásticas (murales) y cinematográficas; el nombre propio, especialmente en mujeres que nacieron en la década de los treinta, $\mathrm{y}$, como anexo, la frecuencia del nombre en los municipios michoacanos desde 1968. Inicia con una reflexión sobre la importancia del nombre propio, especialmente tratándose de un marcador ideológico. Esta primera sección finaliza con un cuadro sinóptico que muestra los usos del nombre Eréndira hasta ahora conocidos, y que se revisan a lo largo del trabajo. Le sigue un apartado que comenta la mezcla de ficción y realidad en el relato de Eduardo Ruiz sobre Eréndira. El tercer apartado presenta información sobre Eduardo Ruiz y la importante presencia de mujeres en sus textos. El cuarto apartado es una síntesis del texto completo de Eréndira en el libro de Eduardo Ruiz. En el siguiente, se destaca la función "espejo" que tiene Eréndira, heroína impecable, con respecto a la Malinche, personaje incómodo para el nacionalismo liberal del XIX. El sexto apartado se centra en los murales de Eréndira y la reducción del texto de Ruiz por el transvase del lenguaje textual al visual, y de ahí al fílmico. En el séptimo apartado se incluye la voz de algunas de las llamadas Eréndira en los años treinta, cuando este nombre era excepcional. Transversalmente, a lo largo de todos los apartados, se dan elementos para ver en contexto la idea de "cultura patriar$\mathrm{cal}^{\prime \prime}$ y la sutil apertura de horizontes que algunos varones, padres de hijas, propiciaron. La ficción de Eréndira, acuñada por varones que nacieron en el XIX, es un relato en el que es central el ingenio y valor de una figura femenina en circunstancias peligrosas. Las desventajas sociales de la protagonista, frente a los invasores y frente a los varones de su grupo, la sitúan en una posición de vulnerabilidad múltiple, a la cual ella responde flexiblemente, ampliando el alcance de sus acciones, entrando en composición con una existencia animal y sorteando los obstá- 
culos que se les enfrentan. Es, también, un nombre-insignia orgullosamente vivido por mujeres en el siglo $\mathrm{xX}$.

Sostengo que, con la leyenda de Eréndira, los murales y su empleo como antropónimo, estamos ante un texto complejo que habla de la interfase cultural entre "lo indígena" y "lo extranjero", subversivo pero también conciliador. Su fuerza imaginativa, su capacidad de crítica política y dignificación de la figura femenina, india y equina, han permitido que la población se lo apropie desde diversos enfoques y con gran libertad. Como marcador de cambio cultural nos señala un hito importante, un posicionamiento político que desde la autoridad paterna y en un contexto androcéntrico, abre posibilidades y horizontes para las hijas.

\section{LA IMPORTANCIA DE LLAMARSE}

Cumpliendo funciones tan importantes, paradójicamente, los antropónimos suelen pasar inadvertidos. Los nombres tienen la misma peculiaridad que observó Merleau-Ponty para el lenguaje en general: su existencia se realiza en su desaparición, como si el encuentro interpersonal fuera inmediato.

Los nombres posibilitan el reconocimiento social de alguien y suelen dar legitimidad a su existencia, marcan la pertenencia a determinado grupo social, hacen legibles a los sujetos ante el Estado, evocan características (sexo, temperamento, virtudes, el comportamiento o destino figurado por quien impuso el nombre... $)^{3} \mathrm{y}$ mantienen relaciones interesantes con la persona nombrada: suplantación, representación icónica, identificación o rechazo total... Para algunos filósofos, los nombres personales no son palabras, no tienen significado, pues la individualidad no puede tratarse como una clase lógica-y un nombre propio no es más que el sonido con que se refiere a la individualidad única e irrepetible- ${ }^{4}$

\footnotetext{
${ }^{3}$ Alford, Naming and identity: a cross-cultural study of personal naming practices, New Haven, HRAF Press, 1988.

${ }^{4}$ Es el caso de los estudios de Bertrand Russell y Wittgeinstein, que recuperaban así una tradición filosófica antigua y medieval. Véase Beuchot, Historia de la filosofía del lenguaje, México, FCE, 2005.
} 
Para otros, los nombres sí comportan significados, en sí mismos y en sus narrativas, sus usos en la práctica y en la política.

Reconocer la arbitrariedad y contingencia del nombre propio no obsta para explorar, a través de un angosto espectro de las prácticas de imposición del nombre personal, la génesis social y despliegue de una "significación imaginaria" en Michoacán desde finales del siglo XIX, a grandes zancadas por el xx y en los comienzos del XxI. Para ello, en primer lugar cabe extrañarse ante el nombre de Eréndira impuesto a mujeres (no he encontrado casos de varones así nombrados) negocios y sitios en Michoacán. ¿Cómo surgió? ¿Cómo se ha venido difundiendo, haciéndose cada vez más común, y entre quiénes?

La voz eréndira aparece en el Arte de la Lengua de Michoacán, de Gilberti ("Erendira. risueño" -sic-), escrito en el XVI. Es éste el significado que le da Eduardo Ruiz en su "leyenda", si bien este autor menciona que la sonrisa de Eréndira tenía algo de gesto altanero. El Diccionario Grande no incluye "erendira", pero sí incluye el verbo "erendirani" para el cual da la equivalencia "Mostrarse alegre, sonreirse". Hoy día este significado no es tan claro para algunos hablantes de purépecha. Me comentaba Néstor Dimas Huacuz: “...quiere decir que trae algo en la boca, que la boca está como llena de algo, o chueca... es que ni siquiera nos suena bonito". ${ }^{5}$

Hubo un tiempo en que no se imponía (o no tan frecuentemente) el nombre de Eréndira a niñas. Su más evidente propagación para los registros actuales fue como nombre de negocio ${ }^{6}$ p propiedades particulares del general Lázaro Cárdenas del Río. ${ }^{7}$ A diferencia de las personas, las propiedades y negocios con este nombre tienen arraigo en un espacio fijo y público, lo que facilita su visibilidad al tiempo que contribuye a la difusión y aceptación del nombre.

No resulta plausible la hipótesis de que el nombre sea originario de pueblos afrocolombianos, arahuacos, guajiros... de donde habría llegado a tierras michoacanas antes del XVI. Esta hipótesis supondría que Gabriel García Márquez oyó el nombre en su infancia, en Colombia, y lo

\footnotetext{
${ }^{5}$ Comunicación personal, Morelia, octubre 2004.

${ }^{6}$ Nieves Eréndira de Pátzcuaro; según su dueño, data de 1907.

${ }^{7}$ Quinta Eréndira, hoy CREFAL; playa Eréndira, en la costa michoacana.
} 
recuperó para su cuento La increible y triste historia de la cándida Eréndira y su abuela desalmada, publicado en 1972. Sin embargo, en esa región nada ni nadie se llama Eréndira. ${ }^{8}$ Además, Gabriel García Márquez ha dicho que escribió su Eréndira en México. Supongo que visitó Michoacán, quizá conoció los murales de Pátzcuaro y pensó que esta leyenda era semejante a las historias de caballería, con Eréndira como una virgo bellatrix, una doncella guerrera.

La siguiente tabla esquematiza los avatares de Eréndira, algunos de los cuales desarrollo con cierto detalle en este trabajo.

\section{Eréndira en:}

Texto híbrido Heroína impecable, vanguardista, nacionalista en tiempos de la historia-ficción, Conquista de Michoacán. Utiliza al caballo como medio para Eduardo Ruiz salvarse de su destino con un varón purépecha (Nanuma), mal (1900) guerrero aliado de los españoles que pretendía someterla como esposa o como esclava. Luego ella ayuda a la evangelización de su gente; se enamoran ella y Fray Martín de la Coruña, quien la bautiza ("Eréndira"); él se hace santo al rechazar la relación sexual con ella.

Leyendas Jovencita asociada con el sacrificio y la aparición de manantiales o populares en fuentes de agua. Secuestrada por un conquistador español que la Pátzcuaroy ocultó en un valle cercano a Pátzcuaro, Eréndira lloró incansableZirahuén. Al mente hasta formar el lago de Zirahuén y murió ahogada en éste. otro lado (Gustavo No hay sentido épico en el relato ni se menciona ningún caballo. Loza 2004)

Murales en Representan el momento de la batalla entre purépechas que resistían Pátzcuaro y a las fuerzas del imperio y sus aliados españoles, según el texto de Jiquilpan Eduardo Ruiz.

(1920-1944)

Eréndira, Con actuaciones de Emilio “indio" Fernández y María Teresa protagonista en Orozco en el papel de Eréndira. Es una historia trágica de abuso de película Janitzio poder de un varón blanco que encarcela al novio de Eréndira para (1935), guión de poder seducirla. Eréndira se sacrifica por su amado pero el pueblo Luis Márquez no le perdona su "traición" (tener relaciones sexuales con un Romay fuereño) y la matan.*

${ }^{8}$ Josh Marcus recorrió Colombia tomando como guía la obra de García Márquez. No encontró nada con este nombre. Comunicación personal, 6 de diciembre de 2006. 


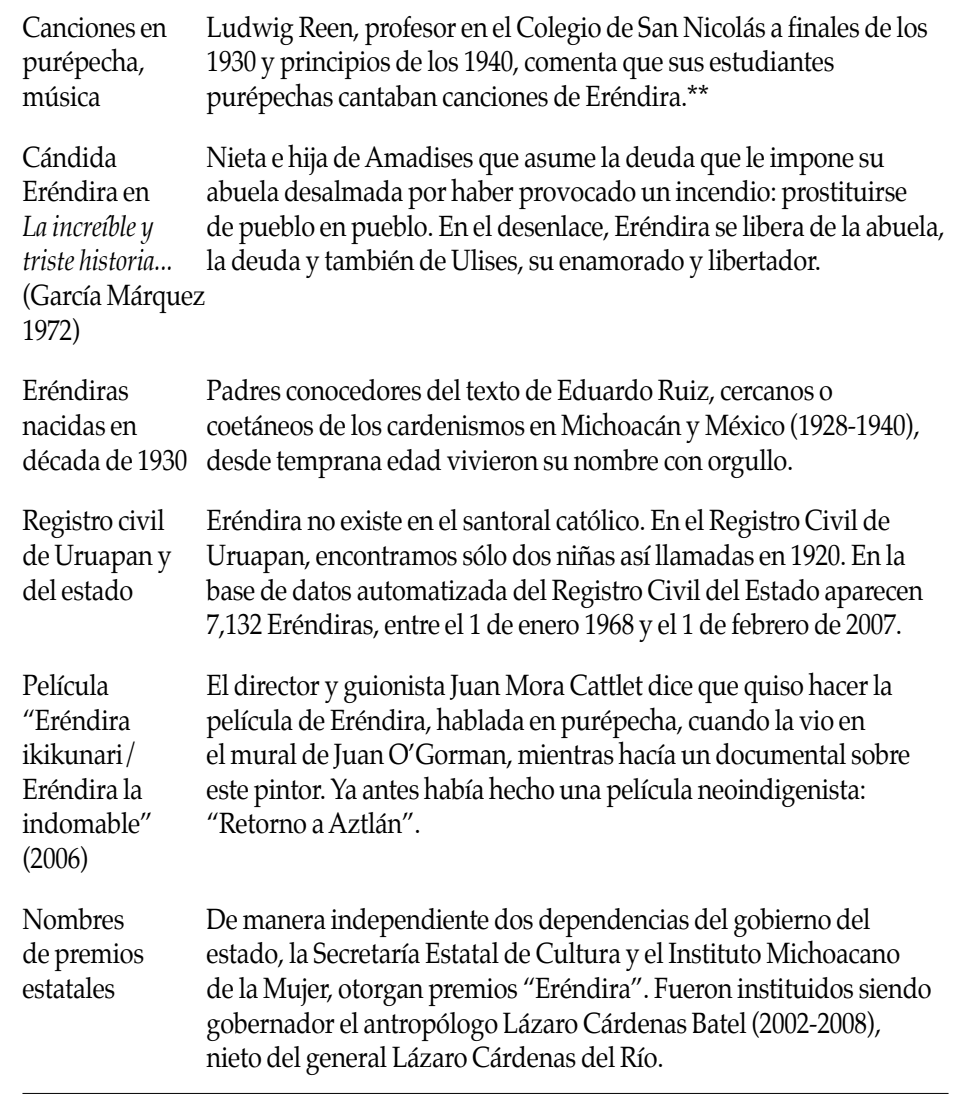

* De 2006 a 2007, Ernesto Peñaloza Méndez fue curador de la exposición de fotos fijas de la película Janitzio (archivo fotográfico Manuel Toussaint, Instituto de Investigaciones Estéticas de la UNAM. Con este tema presentó una ponencia en el 52 Congreso Internacional de Americanistas (2006) donde "analiza la cuestión de la identidad nacional encarnada por la mujer purépecha (apoyada exitosamente en el sexenio cardenista) pero, al final, desplazada por las exuberantes figuras de la Tehuana y de la China poblana, que, junto con el charro de Jalisco, encarnan los tópicos de lo mexicano". Comunicación personal, 22 de octubre de 2006.

${ }^{* *}$ Reen, Morelia, Una Ciudad Universitaria de México, Trad. Josefina Muth de Mier, Morelia, Universidad Michoacana/ CECU, (1951)1991, 88-90. La presente investigación no considera el material musical sobre Eréndira. 
Eréndira, la heroína del calendario Galas de México, la del mural de Juan O'Gorman en Pátzcuaro, la del mural de Fermín Revueltas y Roberto Cueva del Río en Jiquilpan, y la de éste último en la sala de banderas del ahora CREFAL, ${ }^{9}$ la de los varios textos que refríen el relato de Eduardo Ruiz, algunos sumamente didácticos y cargados de mensajes patrióticos ${ }^{10}$ la de la película de Mora Cattlet... no existió.

Eduardo Ruiz adornó con pinceladas de etnoficción la principal fuente histórica sobre el Michoacán prehispánico y los inicios de la colonia, la Relación de Michoacán. ${ }^{11}$

El historiador Benedict Warren asevera contundentemente:

No se ha encontrado a ninguna Eréndira en ninguno de los documentos [de los siglos XVI y XVII] [...] Pero hay una larga tradición española de construir personajes para ocupar un espacio heroico en el paisaje histórico [...] El siglo XIX vio el desarrollo romántico de tales temas y la introducción de grandes

${ }^{9}$ Hay un mural de Roberto Cueva del Río en la biblioteca de la Quinta Eréndira, hoy Sala de Banderas del originalmente llamado Centro Regional de Educación Fundamental para la América Latina (CREFAL), en Pátzcuaro; otro en el hoy Centro de Investigación Interdisciplinaria para el Desarrollo Integral Regional (CIIDIR) del Instituto Politécnico Nacional, en Jiquilpan, la tierra natal de Lázaro Cárdenas. Incluí imágenes en Ana Cristina Ramírez, "Eréndira on horseback. Variations on a Tale of Conquest and Resistance", en Natividad Gutiérrez Chong, coord., Women, Ethnicity, and Nationalisms in Latin America, Ashgate, 2005. "Eréndira a caballo. Acoplamiento de cuerpos e historias en un relato de conquista y resistencia" en e-misférica. Performance and Politics in the Americas, Revista electrónica del Hemispheric Institute for Performance \& Politics (New York University). 2, 2, 2007, 1-19. En línea: http:/ / www.hemisphericinstitute.org/journal/2_2/ramirez. html. Sobre la misión del CREFAL véase el documento fílmico "Camino a la vida" (1958), en http:/ / tariacuri.crefal.edu.mx/crefal/audiovisualistas/videos/camino_vida.htm.

${ }^{10}$ Me refiero, por ejemplo, Rafael Santillán, Eréndira, Zitácuaro, 1972; Huerta, Patamban prehispánico, 2000.

${ }^{11}$ También llamado Códice Escorial (por la biblioteca donde se resguarda el original) o Relación de las ceremonias y ritos y población y gobernación de los indios de la provincia de Michoacán, compilada probablemente alrededor de 1539-1541 por fray Jerónimo de Alcalá para legitimar la versión de la elite uacúsecha sobre su genealogía, la llegada de los españoles y la muerte del último irecha (o rey) Tzintzicha Tanganxoan. Véase http:/ / etzakutarakua.colmich.edu.mx/proyectos/relaciondemichoacan/default.asp 
heroínas [...] Creo que es en este contexto que debemos ver la presentación de Eréndira por Eduardo Ruiz. ${ }^{12}$

Efectivamente, el mismo Ruiz enfrentó en su momento el juicio vertido por Nicolás León, en el sentido de que su entonces muy famoso Michoacán: paisajes, tradiciones y leyendas era "más bien obra de imaginación que de historia". Ruiz lo asentó claramente en el prólogo al primer volumen (1891) y lo reiteró en el prólogo al segundo (1900), donde aparece la leyenda de Eréndira:

expresélas múltiples fuentes de donde tomé la narración, y en casi todas las páginas se ven las numerosas citas que la confirman. Confieso que no escasean los rasgos de imaginación, pero se podrá ver que la mayor parte de ellos están empleados, no en el relato de la historia, sino en las muchas leyendas allí intercaladas [...] El germen de las leyendas está en las obras que he citado y en las tradiciones que me son conocidas desde mi infancia. Yo soy responsable de su desarrollo y el primero en reconocer mi insuficiencia para darles una forma literaria. Mas como en todo relato puede encontrarse algo cierto y bueno, que acaso servirá más tarde para escribir la verdadera historia, declaro que esos datos fidedignos pertenecen principalmente el señor mi padre ${ }^{13} \mathrm{y}$ a las demás personas mencionadas. Y mi deseo de que no se pierdan para la historia de Michoacán estos tesoros que he heredado de personas que ya no existen, es la única disculpa de este libro. ${ }^{14}$

Eduardo Ruiz formaba parte de una generación de escritores que seguía la consigna de Ignacio Manuel Altamirano y Vicente Riva Palacio

\footnotetext{
${ }^{12}$ Warren, "Leyenda de Eréndira. Comentario en la sesión sobre el texto ‘Iconografía de Eréndira', presentado por Ana Cristina Ramírez y Mayra Gabriela Álvarez", Grupo K'waniscuyarani de estudiosos del pueblo p'urhépecha. Pátzcuaro, 30 de julio de 2005.

${ }^{13}$ Toribio Ruiz, nacido en Nurío; liberal, letrado, "líder de la intelectualidad" de Uruapan, según Pedro Talavera, Eduardo Ruiz o el Fausto de la Ciudad del Progreso, Morelia, uMsNH, 1985, 17. Los otros mencionados por Ruiz en el Prólogo a la primera edición son: Martín Cano, Florentino Martínez, Lic. Pedro Eiquihua (con quien leyó la Relación de Michoacán), Lic. Carlos Eiquihua, Melesio Cano, Ramón Vidales, entre otros. En la edición de Balsal de 1971 se lee Eiquihua (pp. 21-22), debiendo ser, seguramente, Equihua, como observó un revisor.

${ }^{14}$ Ruiz, Michoacán, paisajes..., pp. 450-451.
} 
(este último le dirigía cartas llamándolo "ahijado"): la nación necesita inventarse una identidad, cultivar su patriotismo bebiendo en una historia que sea un ejemplo a seguir. Explícitamente la novela era el género recomendado para educar sentimentalmente a una población mayoritariamente analfabeta y ciudadanizarla. ${ }^{15} \mathrm{El}$ horizonte de modernidad que frecuentemente invocan estos autores liberales está inmerso en el contexto político y cultural de México de los siglos XIX, Xx y lo que llevamos del XXI. Incluye referencias a los derechos civiles, sociales y políticos de la población en general, especialmente las mujeres, los procesos de independencia de la América española, en general, y de México en particular, la experiencia traumática y reflexiva de las intervenciones extranjeras, y las propuestas de inventarle, literal y literariamente, un buen pasado a México, un pasado que le diera cohesión e hiciera un poco más difícil que, por ejemplo, la bandera norteamericana ondeara en Palacio Nacional, como ocurrió en 1847.

Durante todo el siglo XIX la narrativa nacionalista mexicana había gastado ingenios con un personaje histórico que difícilmente unificaba la patria: Malintzin, Malinche o doña Marina. En vez de continuar bregando con la polémica reputación de Malinche/ doña Marina, ${ }^{16}$ con la invención de Eréndira Eduardo Ruiz se permite moldear a la india perfecta, así en el momento de resistir la dominación extranjera y la dominación interna por "razones de género", como en el momento de adaptarse a la condición colonial y cristiana, y en el momento de afirmar su deseo sexual; ella es inverosímilmente impecable. Esto lo desarrollo más adelante, al describir el relato de Eduardo Ruiz como espejo de la polémica historia de Malinche.

En la Eréndira de Ruiz observamos la utilización de recursos formales de la literatura de leyendas que surgió en el siglo XVIII en Europa y XIX en América, caracterizada por dirigir una cierta actitud hacia el pasado,

\footnotetext{
${ }^{15}$ Giron, "La idea de "cultura nacional" en el siglo xIx: Altamirano y Ramírez", en Héctor Aguilar Camín (ed.), En torno a la cultura nacional, México, Instituto Nacional Indigenista/Secretaría de Educación Pública, 1976, 51-83; Glantz, "El proyecto cultural nacionalista de Ignacio M. Altamirano" Fractal 31, 2005.

${ }^{16}$ González Hernández, Doña Marina (la Malinche) y la formación de la identidad mexicana, Madrid, Encuentro Ediciones, 2002.
} 
empleando referencias históricas, pseudohistóricas o parahistóricas y yuxtaponiendo la ficción y la "realidad" ${ }^{17}$

El LICENCIAdo EduARDo RuIZ ÁlVAREZ; Un MOdo de FINALIZAR EL ANDROCENTRISMO

Abogado, historiador, periodista, poeta, estudioso del pueblo purépecha, guerrillero del "Partido de la Montaña" contra la intervención francesa en Michoacán, secretario del general Vicente Riva Palacio, Procurador General de Justicia de la Nación, ministro de la Suprema Corte. Fue miembro de prominentes sociedades científicas, merecedor de la Medalla Cuarto Centenario, otorgada por los reyes de España en 1892, conmemorando los 400 años de la llegada de Cristobal Colón a tierras americanas. Murió en Uruapan a consecuencia de una caída montando un potro demasiado brioso. ${ }^{18}$

Fue parte de ese grupo de varones de quienes Carlos Monsiváis ha escrito (sin considerarlo a él):

Un grupo de liberales talentosos, valientes, lúcidos, construye simultáneamente la literatura y la historia de las nuevas libertades. Al edificar "casi de la nada" la República, se enfrentan a los poderes constituidos o con ganas de constituirse, a los representantes de la religión organizada, y al analfabetismo y el caos, el "dúo dinámico" del aislacionismo nacional. Escriben donde pueden y todo el tiempo, toman las armas, redactan las leyes, dirigen secretarías de Estado, viven el nomadismo de la República que cabe en una carroza, resisten al (patético) segundo imperio, atienden al fusilamiento de su emperador y, lo central, están cerca de don Benito Juárez, lo apoyan y lo critican con vigor. ${ }^{19}$

${ }^{17}$ Haberly, “Form and Function in the New World Legend". G. Pérez Firmat (ed.), en Do the Americas Have a Common Literature? Durham/Londres, Duke University Press, 1990,60 .

${ }^{18}$ Hernández, "Eduardo Ruiz, su obra y su tiempo". Tesis de licenciatura en Historia, Universidad Michoacana de San Nicolás de Hidalgo, 1987.

${ }^{19}$ Monsiváis, Las herencias ocultas de la Reforma liberal del siglo XIX, México, Debate, $1993,386$. 
La idea de que la nación está amenazada es uno de los elementos dinámicos de la formación del nacionalismo. En el relato de Eréndira, Eduardo Ruiz proyectó esta amenaza en la llegada de conquistadores españoles a territorio michoacano y el riesgo de que los nativos no comprendieran el sentido de la lucha que debían dar y el uso de las armas traídas del nuevo mundo, por principio, el caballo.

La Relación de Michoacán refiere explícitamente que en el momento de la conquista las mujeres de Tzintzicha Tanganxoan se mostraron aguerridas y con violencia detuvieron el saqueo del tesoro; esto puede ser ya sugerente para la imaginación que busca nuevos héroes. Pero, además, Eduardo Ruiz estaba inclinado a ver a las mujeres y a buscarles un espacio de representación estimulante en el "paisaje histórico". Las mujeres son bastante visibles en su obra, así en la Historia de la Guerra de Intervención en Michoacán, en la historia biográfica, las novelas históricas y en las leyendas. ${ }^{20}$ Ahora bien, en general, a todas ellas las representa como pobres víctimas de la violencia varonil. Incluso cuando son valerosas chinacas hay tonos trágicos en sus vidas y eventualmente son dignas de lástima, obrando siempre por la fuerza del amor y dotadas de virtudes "femeninas": abnegación, humildad, pudor, la fidelidad a un hombre. Casi son excepcionales la figura histórica de Ignacia Riechy la barragana, guerrillera en el Partido de la Montaña ${ }^{21}$, y la figura legendaria de Eréndira, como veremos enseguida.

\section{La ERÉNDIRA De Ruiz, el teXto COMPLeto}

Sobre Eréndira se cuentan relatos diversos y no pocas veces contradictorios. En unos es una valiente guerrera, en otros una doncella llorona. Hay incluso una versión, registrada o inventada por un viajero italiano que visitó Pátzcuaro en los años ochenta, vio el mural de O'Gorman titulado "Historia de Michoacán" en la Biblioteca pública Gertrudis Boca-

\footnotetext{
${ }^{20}$ Escribió una biografía de Ana María Duarte de Iturbide y dio fama a personajes de leyendas purépechas, como Atzimba, Mintzita, Huanita. Talavera, Eduardo Ruiz..., 147148. Véase Clara Guadalupe García, Las mujeres de Ruiz (1863-1867), México, CEHPO, 1998.

${ }^{21}$ Ruiz, Historia de la Guerra de Intervención en Michoacán, Morelia, Balsal, (1896) 1975, 298-299.
} 
negra (donde está la representación más belicosa de Eréndira, enfrentada a caballo con un puñado de guerreros contra una multitud de caballeros conquistadores armados y acorazados), supo de la Eréndira llorona y fundió las dos representaciones en una sola narrativa: Eréndira fue combativa pero cuando vio su tierra perdida para siempre se puso a llorar y formó el lago de Zirahuén. ${ }^{22}$

El texto de Eduardo Ruiz (1900) es, hasta ahora, nuestra primera referencia escrita de la leyenda de Eréndira. Está dividido en seis partes: 1 . "El comienzo de la conquista"; 2 . "La guerra"; 3 . "Humillación y venganza"; 4. "La predicación del Evangelio"; 5. "El sacrificio"; y 6. "La Apoteosis". Cuenta que un grupo de guerreros, encabezados por Timas, repudió la sumisión del irecha o monarca purépecha a los conquistadores españoles; en una fortaleza de Pátzcuaro estos rebeldes enfrentaron al ejército purépecha enviado por el irecha Tzintzicha y que, además, estaba reforzado con cinco jinetes castellanos de las huestes de Cristobal de Olid. Los rebeldes ganaron esa batalla y se apoderaron de un caballo que sería ofrecido en sacrificio a los dioses.

Eréndira, hija de Timas, evitó el sacrificio y pidió para sí el caballo, al cual aprendió a montar en Capacuaro, en la ribera oriental del lago de Pátzcuaro (sic). Nanuma, general de Tzintzicha (sic) quien deseaba someter a Eréndira como esposa o como esclava, dirigió un ataque sorpresivo contra la mansión de Timas en Capacuaro. Asesinaron a Timas y se repartieron sus posesiones y mujeres. Sorpresivamente para los atacantes Eréndira salió montada a caballo; defendió su vida y escapó a los bosques. La tercera parte termina con estas palabras:

Nanuma escogió su botín, a Eréndira, que si no había querido ser su esposa ahora sería su esclava.

Arreglado el reparto todos se apresuraron a penetrar en el aposento para tomar posesión de su presa.

En aquel instante una blanca visión, como la imagen divina de un sueño, apareció en el umbral. Era la hermosa doncella, montada en fantástico corcel, que se abrió paso entre los asesinos, derribando a Nanuma.

Ligera como el viento desapareció entre la espesura de los pinos.

\footnotetext{
${ }^{22}$ Cacucci, El polvo de México, México, Joaquín Mortiz (1996) 2005, 190-192.
} 
El corcoví batió sus alas, brincó de rama en rama y murmuró trinos de alegría. Al mismo tiempo el sol brotaba en el Oriente, llenando el mundo de efluvios luminosos. ${ }^{23}$

Continúa el relato con la conquista espiritual de los remanentes de la población y un incendiario discurso de Eréndira:

Aún permanecía el pueblo en la extensa plaza, aclamando a sus salvadores [los sacerdotes franciscanos recién llegados de México], cuando en lo alto de la yácata apareció Eréndira, tinto de rojo por la indignación, el virginal semblante.

- ¡Purépecha! —exclamó con voz trémula, pero con acento poderoso. Antes vimos a los españoles que vinieron a arrebatarnos nuestros tesoros y nuestras tierras; hoy miramos a estos hombres que llegan como mendigos a apoderarse de los niños como si fuesen huérfanos, a destruir nuestros dioses y a imponernos una religión extraña. ¿Qué nos quedará entonces? ${ }^{24}$

Poco después Eréndira intervino en un momento crítico de la evangelización para interpretar las palabras del misionero franciscano fray Martín de la Coruña y evitar que la muchedumbre lo linchara por profanar un templo, posiblemente en Tzintzuntzan. ${ }^{25}$ En líneas bastante crípticas Ruiz describe un enamoramiento mutuo que alcanzaba el delirio.

Un pasaje clave es el bautismo de Eréndira:

—Padre - le dijo Eréndira - te he seguido a todas partes; te buscaba mi alma, y mis ojos no podían encontrarte. Vas bautizando a mis hermanos, ¿por qué a mí sola me has abandonado?

-Es verdad Eréndira, me haces recordar que tú no has recibido aún las aguas del bautismo: ¡Dios te mandará con ellas la gracia que tanto necesitas! -Que tanto necesito yo también, pensó el sacerdote [...] empapó la cabeza de la joven, y alzando su propio corazón hasta el fondo de los cielos, murmuró: -Yo te bautizo en el nombre del Padre, del Hijo y del Espíritu Santo!.

\footnotetext{
${ }^{23}$ Ruiz, Michoacán... p. 529.

${ }^{24}$ Ruiz, Michoacán... pp. 535-536.

${ }^{25}$ Ruiz, Michoacán... pp. 483-552.
} 
— ¡Ah! Ya soy cristiana — gritó Eréndira.—Ya puedes amarme. Ya no huirás de mí. ¡Ya tenemos un mismo Dios! ${ }^{26}$

Ruiz no dice qué nombre cristiano le impuso fray Martín a Eréndira; extrañamente, ya bautizada siguió identificándose con su nombre pagano. Ésta es una clara señal de que estamos ante una ficción y en modo alguno ante datos históricos. Asombraría que, teniendo el significativo poder de renombrarla, borrar su pasado pagano y darle una nueva marca de identidad religiosa y cultural, el sacerdote dejara intacto su viejo nombre.

Según Ruiz, fray Martín se eleva a la santidad al rechazar la relación sexual con Eréndira a quien tenía desnuda a su lado, apasionada y ya bautizada:

De improvisto, el fraile se desprendió de lado de Eréndira, se hincó de rodillas en medio del aposento, puso sus brazos en cruz, e inclinando su frente, elevó al cielo una plegaria tan fervorosa, despegó de tal manera su alma de los deleites de la tierra, que Dios coronó sus sienes con la diadema de su amor y lo colmó de bendiciones; “le quitó los impulsos de la carne y lo dejó tan puro, que obraba estando en ella como si no estuviera" ${ }^{27}$

Cuando Fr. Martín se levantó del suelo había dejado de ser hombre y se había convertido en ángel.

Eréndira, postrada en el lecho, vertía abundantes lágrimas y sollozaba tan lastimosamente, como si el corazón se le estuviese haciendo pedazos.

En aquel momento la bóveda celeste se cubría de estrellas, y la luna se alzaba en el horizonte como una hostia de castidad..$^{28}$

Muere fray Martín en Pátzcuaro en 1557; Ruiz finaliza el relato acoplando su ficción romántica a la "historia oficial" de Alonso de la Rea sobre de la santidad del franciscano:

\footnotetext{
${ }^{26}$ Ruiz, Michoacán... p. 545.

${ }^{27}$ Ruiz cita a Alonso de la Rea, Crónica de la Provincia de San Pedro y San Pablo de Michoacán.

${ }^{28}$ Ruiz, Michoacán... p. 549.
} 
Era el mes de agosto. Eréndira cogía millares de luciérnagas que, envueltas en capullos de algodón, llevaba a la iglesia: abría el sepulcro, vestía de blanco el cadáver, lo circundaba de aquellas luces animadas, encendía cirios y permanecía largas horas contemplándolo.

"Y dos veces - asienta el cronista La Rea- los clérigos de la ciudad y otros vecinos de ella, le vieron vestido de vestiduras blancas [...] Y en otra ocasión muchas personas lo vieron sobre el sepulcro, cercado de mucha luz y resplandor".

Después... Eréndira se desvaneció en la inmensidad de los tiempos, como se desvanece una hermosa nube en el azul del cielo. ${ }^{29}$

\section{ERÉNDIRA, ESPEJO DE LA MALINCHE ${ }^{30}$}

Eréndira es un relato híbrido, entre historia, novela, leyenda popular y ensayo político. Se ubica en un momento crítico de la historia de la globalización: el "encuentro" entre purépechas y españoles. En el relato completo la heroína tiene un papel que cubre un amplio registro de posiciones políticas, todas correctísimas incluso dentro del difícil equilibrio entre arrojo y virtud femenina que exigía la posición liberal decimonónica.

Ruiz inventó literariamente un personaje histórico femenino que sirviese de ícono e inspiración alternativa, una otra historia, aparentemente fuera de las disputas en las que la historia verosímil está sumida a finales del xix. Una mujer india que en el mismo escenario de la Malinche (violencia, caos, muerte, alianzas, traiciones, transformaciones... todo lo que significó la llegada de los conquistadores españoles al territorio americano en el siglo xvI) tuviese un desempeño impecablemente heroico y progresista. Ningún defecto que justificar, ninguna inferioridad que heredar. Pintó una mujer de gran valor, capaz de traspasar fronteras de género y cultura, articulando así las posiciones más encontradas y transitando, con las armas de la conquista, hacia la resistencia y la coexisten-

${ }^{29}$ Ruiz, Michoacán... p. 552.

${ }^{30}$ La oposición Eréndira versus Malinche está desarrollada con más detalle en la ponencia presentada en el 52 Congreso Internacional de Americanistas, 2006, que continúo trabajando para su publicación. Véase también Mayra Gabriela Álvarez, "Malinche. Lengua y matriz", tesis de licenciatura en Filosofía, UMSNH, Morelia, 2007. 
cia. Dueña de sí, patriota, con ideas propias, pero casta y nulípara, en frontal contraste con la Malinche, a quien la historiografía liberal decimonónica marcaba como traidora, puta, en todo caso redimible sólo por ser madre de mestizos. En el relato de Ruiz, la castidad de Eréndira no es producto de la santurronería, sino un efecto no buscado, pero asumido, de su enamoramiento hacia un santo varón.

Ruiz no explica qué literatura de ficción influenció su obra (lo cual no es reprochable, desde luego) pero sabemos, por su relación personal con Riva Palacio, sus lecturas de la Revista de México, publicada por Ireneo Paz (el abuelo de Octavio Paz y autor de Doña Marina. Novela histórica de 1883) en fin, de ese cosmos en que liberales y conservadores en México y España debaten qué significó para México ser un territorio conquistado y colonizado por España y cuál es la función ideológica de Malinche, "la lengua" de Cortés, la "matriz" de México. El término malinchismo se había difundido desde los años treinta y para 1860 ya era uso común llamar malinchista a quien valora más lo extranjero que lo propio. ${ }^{31}$ El problema de significar genéricamente la relación paradigmática entre Malinche, Cuauhtémoc y Cortés, estaba presente entre los "hombres de letras" de la época de Ruiz.

En su escrutinio de la figura de la Malinche en la literatura mexicana, Cypess recupera la perspectiva de Victor Turner sobre la revolución de Independencia y nos habla de la Malinche como un "paradigma raíz", un modelo cultural que, más allá de la esfera cognitiva y moral, expresa su vitalidad en una serie de dramas sociales. Malinche es para Cypess un palimpsesto donde se inscriben una y otra vez, reformulados, los textos que hablan sobre las relaciones entre varones y mujeres en el contexto temático del nacionalismo. ${ }^{32}$

Más que otro "tipo nacional" (estereotipo) al lado y en competencia con la china poblana, la tehuana, la jarocha, la mestiza de Yucatán..., Eréndira debe entenderse en una relación dinámica y tensa con el personaje histórico del cual es antítesis: doña Marina, la Malinche. La desig-

${ }^{31}$ Monsiváis, "La Malinche y el Malinchismo", La Malinche, sus padres y sus hijos, M. Glantz (ed.). México, Taurus, (1994) 2001, 187-191.

${ }^{32}$ Cypess, La Malinche in Mexican literature from history to myth. Austin, University of Texas Press,1991, 8-13, 70. 
nación de cada una de ellas no se da mediante un regionalismo. Son personajes cuya historia personal concentra la polémica por la moralidad de la nación y lo que uno, una, puede y debe hacer.

La Eréndira de Eduardo Ruiz se halla en el limen entre lo que Cypess llama "el paradigma de Malinche" y un paradigma distinto, alternativo. Como imagen especular de Malinche, Eréndira ciertamente tiene mucho de ella; es su reflejo positivo. Sin embargo, Ruiz introduce elementos imaginados que hacen de este relato algo excepcional. No es una mera inversión en virtud del problema que significó la figura de Malinche para el nacionalismo liberal del siglo XIX. Uno de esos elementos es la refuncionalización del caballo, uno de los instrumentos de la conquista, como aliado para la resistencia, como veremos enseguida.

LAS SUCESIVAS “REDUCCIONES” DEL TEXTO, DEBIDO AL TRASVASE DE

LENGUAJES: DE LETRA A MURO, DE MURO A FOLLETERÍA Y A ACTUACIÓN FÍLMICA

Desde su versión literaria en el libro de Ruiz, Eréndira padece sucesivas reducciones en el mismo proceso que la difunde como imagen. Como un ícono plásticamente representable va perdiendo mucho de ese amplio registro de circunstancias y comportamientos que vimos en el texto. Al final queda solamente la guerrera etérea. De entre todas las imágenes de mujeres e indios a caballo en la historia de la globalización, que son realmente escasas, Eréndira sobresale. Es realmente una imagen excepcional.

Ahora bien, al mostrarse en muros públicos y ser parte del discurso visual oficial, Eréndira deja de leerse. ${ }^{33}$ El texto de Eduardo Ruiz incluso se pierde del marco de referencia de los incontables refritos de la leyen-

${ }^{33}$ Entre 1971 (Balsal) y 2000 (Morevallado) no se editó Michoacán. Paisajes, tradiciones y leyendas. Los críticos literarios e historiadores de la literatura nacionalista del XIX (por ejemplo, Giron 1976, Glantz 2005, Monsiváis 1993) han omitido toda mención a Eduardo Ruiz y su obra. Incluso escritores que sí le dedican espacio y le tienen aprecio al personaje o al Lic. Ruiz o los cardenismos, como Jesús Romero Flores (1960), presentan una lectura parcial del texto de Ruiz sobre Eréndira, quedándose con la guerrera y cortando la faceta de ella enamorada de fray Martín de la Coruña. Los pintores, por la misma naturaleza de su trabajo, se limitan a representar el pasaje, indispensable sin duda, de Eréndira a caballo. 
da, que cada vez la "pintan" más audaz, más conscientemente anticolonial, antiimperialista. ${ }^{34}$

Para los artistas plásticos es ineludible representar lo que Eduardo Ruiz omitió describir en su texto: cómo va Eréndira a caballo. La corporalidad femenina en este tipo de montaje fue un elemento patente en las guerras morales y jurídicas, especialmente a finales del siglo xIx y durante la primera mitad del xx. Antes incluso que la lucha por el sufragio femenino, las naciones "civilizadas" debatieron fuertemente sobre los peligros para la salud personal, la decencia y el vigor de la raza "nacional" si se permitía que las mujeres montaran a horcajadas. Los médicos señalaban riesgos de deformidad en el aparato reproductor femenino, $y$, en consecuencia, hablaban de una posible "degeneración de la raza"; algunos políticos añadían a la deformación física, el atentado a la moral, pues las mujeres que osan montar como hombres, sólo lo hacen por falta de modestia, por deseo de igualdad y de hacerse a sí mismas "indebidamente conspicuas" ${ }^{\prime \prime 5}$ destacados caballistas las condenaban por hacer una monta de mamarracho ${ }^{36}$ e incluso expertas amazonas estaban convencidas de la imposibilidad de montar bien a horcajadas siendo mujer, debido a la redondez de los muslos. ${ }^{37}$

Pero en los caminos y los montes es difícil controlar quién anda a caballo y cómo. Esto ya se había visto en el XVI, cuando las restricciones para que los nativos americanos cabalgaran quedaron ampliamente rebasadas por la dinámica de las poblaciones de caballos, de nativos y de las instancias que administraban el gobierno colonial y la aplicación de la ley.38

\footnotetext{
${ }^{34}$ Romero Flores, Diccionario michoacano de historia y geografía, Morelia, Talleres Tipográficos de la Escuela Técnica Industrial “Alvaro Obregón”, 1960; Salas León, Pátzcuaro: cosas de antaño y hogaño, Morelia, Ed. del autor, 1968; Santillán, Eréndira...; Huerta, Patamban prehispánico.

${ }^{35}$ Legislador en Georgia, introduciendo una propuesta de ley, en 1910. Citado en Pierson, Dark horses and black beauties: animals, women, a passion, Norton, Nueva York, 2000, 61-63.

${ }^{36}$ Dodge, Riders of many lands, Osgood, Mcllvaine, 1894, 480-482.

${ }^{37}$ Welton, “La Amazona", Revista de Equitación, México, Secretaría de Guerra, 1930, $44-45$.

${ }^{38}$ Véase Du Bron, “Le cheval Mexicain en Nouvelle-Espagne entre 1519 et 1639", tesis de doctorado en Historia, École des Hautes Études en Sciences Sociales, París, 2010.
} 
Una Eréndira pudorosa, una dama que no expone sus genitales al contacto con el lomo del caballo, como la del mural de la Sala de Banderas del CREFAL, es parte de una historia matizadamente distinta de la otra, la Eréndira caballera, que no marca corporalmente su diferencia con la forma de montar del conquistador y que se nos muestra con pleno dominio de la bestia que contiene entre sus piernas -es el caso del mural de la Biblioteca Gertrudis Bocanegra-. Además, la Eréndira que monta "a mujeriegas" es también la más cubierta por su vestido, de hombros a tobillos; la Eréndira combativa va semidesnuda, con el torso y piernas al descubierto. ${ }^{39}$

Las variaciones iconográficas de Eréndira a caballo cuentan historias diferentes en los muros y relieves de la misma ciudad de Pátzcuaro. El "problema" de la representación visual es precisamente el encanto de la composición y el foco de atención para quien lee las dinámicas que se introducen cuando se ven caballos y jinetes en movimiento. El relato de Eréndira no se refiere a una mujer intérprete en medio de la conquista, como puede ser el caso de Malinche; se refiere a una mujer a caballo. La bestia debe ser vista. El caballo es el elemento crucial de dominio bélico intencional ${ }^{40}$ porque conjunta velocidad, fuerza y voluntad, y los pone a disposición del jinete que ha sabido pedírselos, sin distinguir sexo, región geográfica de procedencia, religión o idearios políticos.

El rastro de la narrativa plástica que la devoción cardenista fue dejando en -al menos- Pátzcuaro y Jiquilpan no es sólo una ocurrencia reiterada; más bien expresa el gusto del general Cárdenas por ver el acoplamiento orgánico y técnico más decisivo en el nivel civilizatorio: el binomio de caballo y jinete. Y verlo en esta narrativa de resistencia y apropiación, aunque sea tan notablemente ambigua. Este relato crítico del colonialismo se inventa y reinterpreta en la segunda mitad del XIX y, nuevamente, en la primera del xx. La iconografía de una mujer purépecha a caballo en situación de peligro se nos despliega en una gama de matices que narran historias igualmente diferentes. Pensemos en esto como una inquietante riqueza visual aportada por el reto que ha impli-

\footnotetext{
${ }^{39}$ Véase nota 11.

${ }^{40} \mathrm{Con}$ "intencional" distingo al caballo de otras armas terribles que llegaron de Europa y diezmaron la población aborigen: infecciones y plagas.
} 
cado para los artistas plásticos montar a caballo a una purépecha en medio de un ataque.

Pero la riqueza de versiones no sólo sobreviene por la laguna que dejó el relato escrito, sino por algo fundamental en el mismo: Eréndira es un emblema de la voluntad de autonomía que no se niega a comprender lo que la amenaza; ella agudamente observa cómo se transporta su enemigo y cómo este agente del invasor -el caballo- puede ser redirigido y convertirse en un aliado. La riqueza del relato de Eréndira no sólo estriba en que cada quien le invente un poco a lo que ya se ignora; es rico porque valora simultáneamente la voluntad y el entendimiento, la resistencia y la apertura, la tenacidad y la capacidad de alianza.

Observamos así tres transfiguraciones cronológicamente desplegadas, expresadas con los recursos técnicos disponibles en cada momento histórico. La primera ocurre al quedar plasmada la leyenda en el texto de Ruiz, montando a una alter Malinche a caballo en los acontecimientos de la conquista y la colonia. La segunda, al pasar del texto de Ruiz a pinturas murales, que fijan la atención en Eréndira a caballo. En su tercera y última transfiguración, Eréndira ya no es sólo un texto de un novelista e historiador porfiriano, ya no es sólo "una sombra" en la pared de un centro educativo. ${ }^{41}$ Eréndira es actuada, hablada en el purépecha serrano, filmada en cámara digital y llevada al cine para que cientos de personas, simultáneamente, dirijamos la mirada al drama que representa. Es el caso de la película Eréndira Ikikunari/Eréndira la indomable (2006), con guión y dirección de Juan Roberto Mora Cattlet.

Mora Cattlet ya había escrito y dirigido Retorno a Aztlán, hablada en náhuatl y ubicada poco antes de la llegada de los españoles, que recrea la atmósfera mística de los aztecas pero también su estratificación clasista. Tanto Retorno a Aztlán como Eréndira superan la lectura maniquea de la historia (indios buenos, españoles malos), mostrando relaciones sociales complejas. Para Mora Cattlet es relevante el acercamiento a la verdad desde el cine. En Eréndira pretende recrear, mediante un realismo un tanto barroco, el momento "metafísico" del mestizaje: que una indígena supere la distancia entre la bestia traída de otro mundo y la dirija,

${ }^{41}$ Masters, Shadows on a wall: Juan O'Gorman and the mural in Pátzcuaro, Pittsburgh, University of Pittsburgh Press, 2005. 
como un arma, como un aliado, contra los extranjeros invasores. El director declara: "El indio a caballo es el mestizo". ${ }^{42}$

Mora Cattlet consideró que la Eréndira "auténtica" era la aguerrida, la indomable del mural de O'Gorman; no la que salva al fraile franciscano de la multitud que está a punto de lincharlo, que luego, enamorada, se convierte al cristianismo y colabora en la evangelización. Esta otra faceta le parece una impostura atribuible a la moral de la época en que escribió Eduardo Ruiz. ${ }^{43}$

Ya no sólo vemos el drama de Eréndira, el caballo, los purépechas y los españoles en 1522. Vemos el drama de la representación masculina del ideal liberal femenino a finales del XIX y cómo, selectivamente, en el XXI se destaca uno $u$ otro aspecto de un personaje complejo. Finalmente, veremos cómo las mujeres de carne y hueso responden al reto de nombrarse Eréndira.

\section{LAS ASÍ LLAMADAS ERÉNDIRA}

Los antropónimos o nombres personales son particularmente interesantes para las investigaciones en historia y antropología. Imponer un nombre es un acto obligatorio, pero la elección del nombre se realiza con relativa libertad; por ello son un instrumento interesante para el estudio de los cambios sociales a lo largo del tiempo. ${ }^{44}$

En el archivo histórico del Registro Civil de Uruapan (uno de los municipios en donde hay más Eréndiras), encontramos sólo dos niñas asíllamadas en 1920; luego no aparece el nombre nuevamente sino hasta 1936. De ahí en adelante se registra al menos una vez casi todos los años; conforme avanzamos en el siglo Xx se vuelve más y más frecuente.

Una de las primeras, si bien no nació ni fue registrada en Michoacán, sino en el Distrito Federal en 1935, es María Eréndira Anguiano Roch. Hija del licenciado Victoriano Anguiano Equihua, abogado purépecha

\footnotetext{
${ }^{42}$ Diario Provincia, Suplemento Cortometraje, Morelia, Mich., 18 de octubre de 2006, p. 3.

${ }^{43}$ Mora Cattlet, comunicación personal, 23 de julio de 2007.

${ }^{44}$ Smith-Bannister, Names and naming patterns in England, 1538-1700, Oxford historical monographs, Oxford/Nueva York, Clarendon Press/Oxford University Press, 1997.
} 
originario de San Juan de las Colchas o Parangaricutiro (el pueblo que destruyó la erupción del volcán Parícutin en 1943), cuyo padre fue asesinado por cristeros en 1928, lo cual lo obligó a dejar sus estudios de Derecho en el Distrito Federal y continuarlos en Morelia. ${ }^{45}$ Anguiano ayudó al joven general Cárdenas en su campaña para ser gobernador de Michoacán (1928-1932) como orador en mítines, intérprete y consejero. Durante el gobierno de Benigno Serrato (1932-1935), Anguiano fue Secretario de Gobierno. También ocupó cargos de diputado federal, profesor en la UnAM de Historia Universal e Historia de América, Rector de la Universidad Michoacana. Fue un hombre cercano José Vasconcelos y al gobierno del general Félix Ireta en sus inicios.

Sin duda, Victoriano Anguiano estaba perfectamente al tanto del relato de Eduardo Ruiz y su significado épico nacionalista cuando eligió nombrar María Eréndira a su hija. Probablemente fueron parientes suyos por su lado materno (Margarita Equihua Gallegos), los varios Equihua que Eduardo Ruiz refiere en el Prólogo al primer volumen de Michoacán. Paisajes, leyendas y tradiciones. Entrevistada, Eréndira Anguiano, comentó:

Me hace sentir muy orgullosa llevar, como una parte de mi herencia paterna, el nombre que mi padre me puso. Nunca hablamos de ello, pero yo siempre entendí que para mi padre era muy significativo, que él sabía la envergadura de la leyenda, tras este nombre. Uno de sus hermanos, mi tío Luis, se casó con Consuelo Martínez López, quien fuera por más de cuarenta años una maestra muy querida en Paracho; todas sus hijas llevan nombres p'urhépecha: Janikua, Yurítzkiri, Erandi, Ireri, Yunuén. Mi abuelo paterno, Hermenegildo Anguiano, era un hombre instruido, había estado en el seminario. ${ }^{46}$

\footnotetext{
${ }^{45}$ Anguiano Equihua, Lázaro Cárdenas: su feudo y la política nacional / Con un juicio de José Vasconcelos y prólogo de Manuel Moreno Sánchez, México, Eréndira/Cvltura, 1951. Véase también Oikión, "Victoriano Anguiano Equihua (1908-1958)", en Gerardo Sánchez y Ricardo León, coords., Crecer sobre las raíces. Historiadores de Michoacán en el siglo XX, Universidad Michoacana, Morelia, 2002, 157-162.

${ }^{46}$ Gloria Cáceres, entrevista con María Eréndira Anguiano Roch, Morelia, Michoacán, 17 de noviembre, 2004.
} 
Sobre lo inusual que resultaba su nombre en los años cuarenta, Eréndira Anguiano comenta:

al principio cuando estaba muy chiquilla en la primaria, me sentía rara, todo mundo preguntaba de dónde era ese nombre, qué quería decir, por qué me llamaba así [...] entre la secundaria y la prepa me encontré con una compañera que se llamaba Guadalupe Eréndira Hoyo [...] ella venía del estado de Hidalgo, de gente intelectual, de gente que actuaba en la política. Su padre era gobernador de Hidalgo, contemporáneo, más o menos, de mi padre.

Viviendo en la India en una estancia diplomática de su esposo, Eréndira Anguiano fue "madrina" de una niña a la que sus padres llamaron Eréndira, nombre que sonaría en aquel país como una variante de Indira.

Victoriano Anguiano escribió artículos sobre el cardenismo como una empresa con doble rostro, como Jano, el dios romano: es revolucionario pero también feudal y autoritario. Anguiano criticó ciertos aspectos de la política cardenista, tales como la cooptación de las organizaciones populares, el paternalismo y la falta de democracia ${ }^{47}$ Su libro Lázaro Cárdenas: su feudo y la política nacional apareció en la editorial "Eréndi$\mathrm{ra}^{\prime \prime}{ }^{48}$ Tras su muerte, acaecida el 13 de junio de 1958, el periodista José Alvarado publicó unas líneas que captan sus rasgos esenciales: "Victoriano Anguiano [...] combatiente y combatido, fue un político que tuvo inextinguible amor a la pelea y supo elegir, además, adversarios gigantescos. Inteligencia singular, pasión por la vida mexicana, fueron las mejores armas de este hombre del más puro origen indígena, purépecha".

La experiencia de Eréndira María del Pilar de la Peña Fuentes, nacida en 1936, es también de cercanía con los cardenismos y conocimiento de las referencias textuales disponibles. Ella es hija del ingeniero agrónomo Rosendo de la Peña Valdés, quien nació en Morelia en 1901, y de María del Pilar Fuentes, originaria de Tenancingo, Estado de México. No hablaban purépecha, pero su padre leyó el libro de Eduardo Ruiz y le quiso poner ese nombre a su primera hija. El sacerdote que la bautizó

\footnotetext{
${ }^{47}$ Anguiano, Lázaro Cárdenas...

${ }^{48}$ En el colofón se dice que es la editorial Cvltura. Gracias a Eréndira Anguiano por esta observación.
} 
se opuso tajantemente a que sólo llevara un nombre pagano. “Me pusieron el María del Pilar, por mi madre, pero sólo para salir del paso. Jamás lo he usado y mi padre no era afecto a los nombres largos o compuestos". ${ }^{49}$ Su padre trabajó para el general Cárdenas en el Banco Ejidal, y con Dámaso Cárdenas en otros proyectos, como el diseño de la fuente de Las Tarascas, en Morelia. Ella comenta:

Nacimos en una época en la que la gente le ponía nombres extranjeros a sus hijos: Karen, Elizabeth... ya no eran las Victorias y Martas de otros tiempos. Que a mí me pusieran Eréndira sí que era significativo, era un punto de referencia, que siempre me abrió puertas y me hizo ser recordada. Me siento realmente muy orgullosa de llevar este nombre, que me distingue en todas partes.

Al salir de la secundaria en Uruapan, Eréndira ingresó a la Universidad Femenina de México. Concluyó la carrera de laboratorista y analista clínico en los años cincuenta. A ella y a otras muchachas de su edad se les había alentado a ser valientes y superarse. Eréndira de la Peña recuerda el contexto:

Era una necesidad del entorno inmediato uruapense. Los muchachos estaban saliendo a prepararse [...] Veíamos la historia de muchas compañeras que terminado la primaria se casaban. Los maridos se van a donde hay trabajo y las depositan en casa de los padres de ellas, con uno o dos hijos. Luego ellos hacen su vida con otra mujer, en la ciudad.

Al salir de la carrera, Eréndira de la Peña empezó a trabajar en el Hospital Central Militar en el Distrito Federal; ahí se encontró con un ambiente y una mentalidad mucho más abierta que la que había visto hasta entonces, especialmente en su voluntariado en la Cruz Roja, entonces a cargo de monjas. "En el Hospital central mi nombre no era común, pero tampoco era tan raro. Ahí me encontré con Citlalis y Xóchitls, que nunca me había topado con ninguna".

${ }^{49}$ Ana Cristina Ramírez, entrevista con Eréndira de la Peña Fuentes, Uruapan, Mich., 26 de julio de 2007. 
En Uruapan fue compañera y amiga de otra Eréndira, Eréndira Cerda Wigens. Sus padres tampoco eran hablantes del purépecha. Eréndira de la Peña comenta que el pintor uruapense Manuel Ocaranza, de quien guarda obra pictórica, "siempre quiso encontrar una Eréndira de nombre que se correspondiera con el físico indígena y nunca la encontró. Las Eréndiras que conoció eran más o menos como yo, demasiado güeras y de ojo claro". ${ }^{50}$

Conforme Eréndira deja de ser un nombre extraordinariamente raro se va imponiendo con mayor facilidad a más niñas, empresas o lugares, no siempre porque quien ejerce el poder de nombrar -padres o propietarios, generalmente- conozcan sobre la heroína purépecha, la legitimación política de los cardenismos, el sentido de nombre autóctono o la visibilidad de los murales... Así por ejemplo, una Eréndira nacida en 1976 en Monterrey, Nuevo León, recibió ese nombre porque su padre, trabajando en una empresa constructora, viajó al Puerto Lázaro Cárdenas, en Michoacán, visitó Playa Eréndira, le gustó y así la nombró. Otra Eréndira, nacida en 1997 en Apatzingán, lo recibió no por otra cosa sino porque a su mamá le pareció "no tan choteado como otros".

\section{CONCLUSIÓN}

En esta investigación el nombre personal (antropónimo) es empleado para detectar y analizar sus significados en tanto instancia localizada en procesos espacio-temporales más amplios y como un marcador de dinámicas donde se relacionan formas de poder y saber.

Tras el nombre de Eréndira hay varias narrativas que vinculan las historias locales y personales con procesos políticos mucho más amplios. La leyenda de una heroína purépecha que utilizó un caballo para huir o enfrentar a los conquistadores españoles y sus aliados aporta una poderosa imagen que fascinó a uno de los más destacados estadistas de México, el general Lázaro Cárdenas.

${ }^{50}$ Este comentario alienta a seguir buscando textos anteriores al de Ruiz o mujeres nombradas Eréndira antes del siglo xx. También interesa la estética de "tipos" étnicos de Manuel Ocaranza. 
Los mensajes políticos en torno a la leyenda de Eréndira (y el nombre) no son claros ni unívocos y para muchas personas pasan inadvertidos. Con todo, la función de una leyenda es mezclarse con la historia y despertar imaginativamente al auditorio que escucha el relato. Se destaca, para la primera mitad del xx, el cambio social asociado a la crítica al colonialismo, reevaluación de lo indígena y su capacidad para adaptarse creativamente en circunstancias difíciles.

Eréndira se popularizó como nombre de pila a la sombra del experimento político de transvaloración de "lo femenino" y las mujeres que se dio a finales del XIX y primera mitad de XX. La construcción de la ciudadanía femenina en el México posrevolucionario estuvo, como señala Jocelyn Olcott marcada por la ambivalencia de los cardenismos y las complejas relaciones entre proyectos revolucionarios y resultados conservadores.

El cardenismo no ha sido un fenómeno político simple ni con una sola forma de expresión. Mientras que algunos enfoques destacan la sensibilidad del general Cárdenas a las aspiraciones populares, otros subrayan el carácter mítico del poder presidencial y la ausencia de justicia y democracia que prevaleció en los regímenes posrevolucionarios. ${ }^{51}$ Jocelyn Olcott ha mostrado cómo las mujeres en la "era cardenista" (1928-1940) fueron impulsadas para organizarse y cómo alcanzaron espacios políticos de gran visibilidad, al punto de que casi lograron la ciudadanía (derecho al voto); sin embargo, sus esfuerzos fueron desviados $\mathrm{y}$ transformados justo en otra manera de reafirmar el patriarcado:

Viendo a las mujeres como poseedoras de una moralidad natural, Cárdenas consideró que su labor debía ser la de extirpar el vicio y la corrupción [...] Para 1936, el proyecto nacional cardenista ya había eclipsado a su antecedente michoacano. La organización nacional de las multitudes sobrepasó y eventualmente obvió a sus contrapartes del nivel estatal [...] El cambiante clima político nacional movió el centro del activismo de las mujeres en Michoacán de las campañas antialcohólicas y las ligas anticlericales a organizaciones

${ }^{51}$ Spenser y Bradley, "Linking State and Society in Discourse and Action: Political and Cultural Studies of the Cardenas Era in Mexico", Latin American Research Review , 34 (2), 1999, 227-245. 
masivas y sindicatos [...] En resumen, a pesar de que los cardenistas vinculaban estas actividades [organización comunitaria, aprendizaje de liderazgo y experiencia en negociación] con una feminidad esencializada, las ligas condujeron a las mujeres al ámbito masculinizado de la praxis política. ${ }^{52}$

La centralidad de la mujer purépecha a caballo en el relato de Eréndira subraya su condición de coagente en insurgencias múltiples. Hacia finales del siglo xx el relato sigue vigente, con tonos mucho más radicales en su confrontación con el colonialismo que se imagina hubo en el XVI, y con mucha más ligereza en la imposición del nombre de Eréndira a niñas recién nacidas, propiedades o negocios.

ANEXo

Presento un mapa de Michoacán con división municipal y un par de gráficas obtenidas a partir de la información aportada por el departamento de informática del Registro Civil. El total de registros "Eréndira" es de 7,132 en una base de datos automatizada que incluye datos de todo el estado desde 1968 hasta 2007.

Los datos tienen las siguientes limitaciones: 1) No informan: fecha y lugar de nacimiento; datos de padre y madre (edades, procedencia, idiomas, escolaridad, afiliación ideológica o partidista, religión); 2) Eréndira como criterio de búsqueda en la base de datos permite conocer variantes que la incluyan así (Ej. Heréndira, Neréndira y Yeréndira), pero no variantes con menos letras (Erendir) o con otra grafía (Eréntira, Aréndira, Eyréndira, Erándira, etc.); 3) aparecen 322 registros sin especificar municipio.

\footnotetext{
${ }^{52}$ Seeing women as imbued with natural morality, Cárdenas enlisted their support in rooting out vice and corruption [...]. By 1936, the national cardenista project had eclipsed its Michoacán antecedent. National mass organization overshadowed and eventually obviated their state-level counterparts [...] The changing national political climate moved the center of women's activism in Michoacán from temperance and anticlerical leagues to mass organizations and labor unions [...] In short, despite the cardenistas' linking of these activities [community organizing, leadership training and experience negotiating] with an essentialized femininity, the leagues drew women into the masculinized realm of political praxis. Olcott, Revolutionary women in postrevolutionary Mexico, Next wave, Durham, Duke University Press, 2005, 72, 89, 91.
} 
En el mapa de división municipal de Michoacán aparecen cinco rangos de datos según la frecuencia de registros. Dejé en blanco los municipios que no tienen registrada ninguna Eréndira (Chucándiro, Purépero, Queréndaro y Tlazazalca), en el siguiente tono de gris los municipios con menos de 10 registros, con gris un poco más intenso los que tienen hasta 40 registros; finalmente, con negro marqué los municipios con más de 81 registros.

Podemos observar que son pocos (4) los municipios donde no hay ninguna Eréndira registrada, y que aquellos municipios donde hay más registros son los que concentran más población y servicios, pero también donde hay referencias históricas o "turísticas" claras con este nombre: playa Eréndira en el caso del municipio de Lázaro Cárdenas, los murales en el caso de Pátzcuaro, el libro del profesor Santillán en el caso de Zitácuaro.

Pensando en hacer una comparación que relacionara la frecuencia del registro de nombres y la población femenina según el último conteo de población del INEGI (2005) diseñéla gráfica de barras 1. Sólo considero los 11 municipios con mayor frecuencia de registros (los 10 de negro del mapa, más Paracho). Podemos apreciar así que Apatzingán y Pátzcuaro parecen tener más registros por población femenina que otros municipios.

En general, ninguno de los municipios con mayor frecuencia de registros tiene un porcentaje alto de población de cinco y más años que hablan lengua indígena (II Conteo INEGI 2005). Paracho es el único caso en que coinciden números altos de frecuencia de Eréndiras (36) con porcentaje de población mayor de cinco años que habla lengua indígena (34 por ciento). Le sigue Pátzcuaro con 125 Eréndiras y 5.7 por ciento de población que habla lengua indígena. Una primera impresión nos hace sostener que los municipios con mayor número de registros de Eréndiras no son los de mayor porcentaje de hablantes de lengua indígena.

La gráfica 2 representa la frecuencia con que encontramos el nombre Eréndira combinado con un nombre "cristiano" (por ejemplo: María Eréndira), que es la mayoría (74 por ciento); los registros de sólo Eréndira son una cuarta parte ( 25 por ciento). En contraste, los registros de Eréndira combinados con otro nombre fuera del santoral católico ${ }^{53}$ sólo representan 1 por ciento.

${ }^{53}$ Sólo consideré los nombres claramente autóctonos según mi limitado entender. 
Esta visualización me pareció interesante a la luz de referencias a que el sacerdote católico se negó a imponerle solamente un nombre pagano a la niña bautizada. El nombre combinado permite presentarse con uno u otro o ambos. En contraste, una informante (de Patamban) y su esposo (de Oaxaca) nombraron a su hija Eréndira Donají, a finales de los ochenta, combinando así nombres autóctonos de Michoacán y Oaxaca en lo que podríamos considerar una declaración política; ella me comentó que en el bautizo el sacerdote se extrañó y les preguntó "iy por qué no un nombre cristiano?", pero aceptó realizar el rito luego de que ellos insistieron un poco más.

MAPA DE FRECUENCIA DE REGISTRO ERÉNDIRA POR MUNICIPIOS

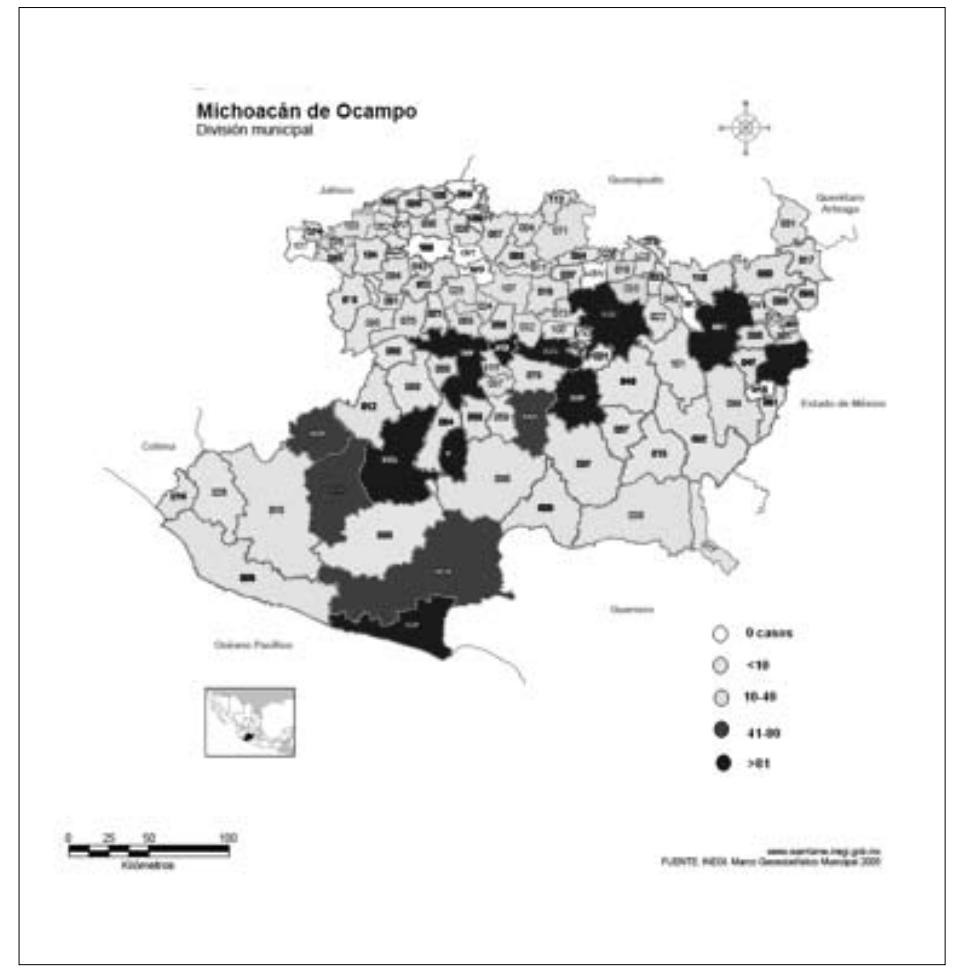


Gráfica 1. ERéndira. Frecuencia del nombre en el Registro Civil DESDE 1968

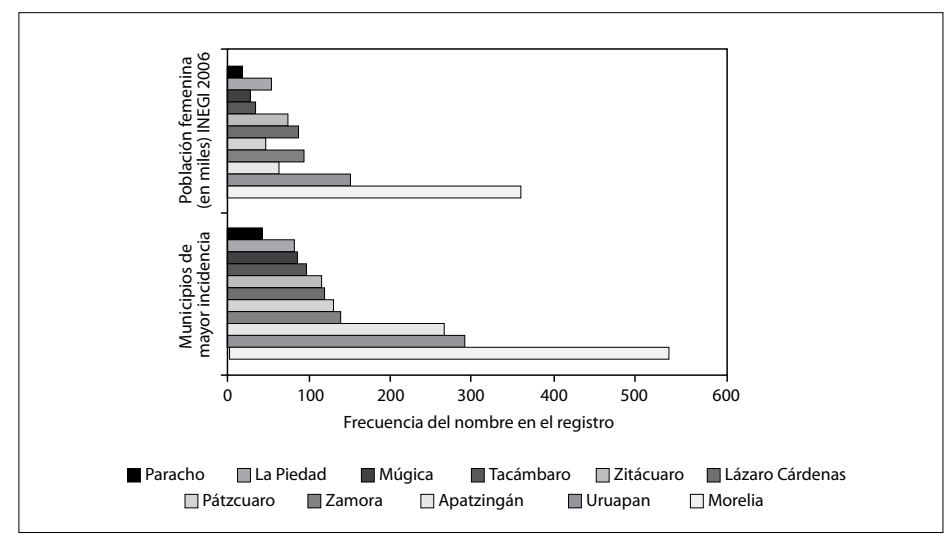

GRÁFICA 2. ERÉNDIRA, SOLO Y COMBINADO

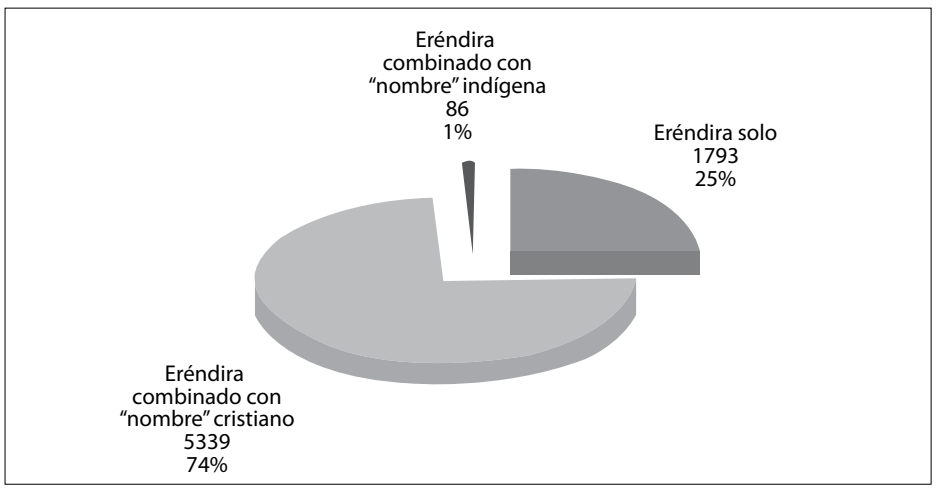

BiBLIOGRAFÍA

ALFORD, Richard D., Naming and identity: a cross-cultural study of personal naming practices, New Haven, HRAF Press, 1988.

ÁlvAREZ, Mayra Gabriela, "Malinche. Lengua y matriz", tesis de licenciatura en Filosofía, Universidad Michoacana de San Nicolás de Hidalgo, Morelia, 2007.

ANGUIANo EQUiHuA, Victoriano, Lázaro Cárdenas: su feudo y la política nacio- 
nal / Con un juicio de José Vasconcelos y prólogo de Manuel Moreno Sánchez, México, Eréndira, 1951.

Beuchot Puente, Mauricio, Historia de la filosofía del lenguaje, México, FCE, 2005.

CACucci, Pino, El polvo de México, México, Editorial J. Mortiz, 1996.

CYPESS, Sandra Messinger, La Malinche in Mexican literature from history to myth, Austin, University of Texas Press, 1991.

Diccionario grande de la lengua de Michoacán, Introducción, paleografía y notas de J. Benedict Warren, Morelia, Fímax publicistas.

Dodge, Theodore Ayrault, Riders of many lands, Osgood, Mcllvaine, 1894.

Du BRON, Marion, "Le cheval Mexicain en Nouvelle-Espagne entre 1519 et 1639“, Tesis de doctorado en historia, École des Hautes Études en Sciences Sociales, París, 2010.

García, Clara Guadalupe, Las mujeres de Ruiz: la participación femenina durante la intervención francesa en Michoacán, en la obra de Eduardo Ruiz, 1. ed., Biblioteca del Centro de Estudios Históricos del Porfiriato, México, Centro de Estudios Históricos del Porfiriato, 1998.

García MÁrquEz, Gabriel, La increible y triste historia de la cándida Eréndira y de su abuela desalmada; siete cuentos, Barcelona, Barral Editores, 1972.

GilberTI, Maturino, Arte de la lengua de Michuacan compilada por el muy Reverendo padre fray Maturino Gylberti de la orden del Seraphico padre Sant Francisco, de regular observancia. Año de 1558, Introducción histórica con apéndice documental y preparación fotográfica del texto por J. Benedict Warren, Morelia, Fímax publicistas, (1558) 1987.

GIRON, Nicole, "La idea de 'cultura nacional' en el siglo xIX: Altamirano y Ramírez", En torno a la cultura nacional, Héctor Aguilar Camín (ed.), México, Instituto Nacional Indigenista/Secretaría de Educación Pública, 1976, 51-83.

GLANTZ, Margo, "El proyecto cultural nacionalista de Ignacio M. Altamirano», Fractal 31, 2005.

GonZÁlez HeRnÁNDEZ, Cristina, Doña Marina (la Malinche) y la formación de la identidad mexicana, Madrid, Encuentro Ediciones, 2002.

HaberLy, David T. "Form and Function in the New World Legend". Do the Americas Have a Common Literature? G. Pérez Firmat (ed.), Durham/Londres, Duke University Press, 1990. 
Hernández, Pável, Eduardo Ruiz, su obra y su tiempo, B.A. Tesis en Historia, Universidad Michoacana de San Nicolás de Hidalgo, 1987.

HuerTa Ruiz, José Luis, Patamban Prehispánico -Sobre Eréndira, Monarca, Expresión de lo nuestro, s/f [16/07 2005]. Disponible en http:/ / www.monarcaonline.com.mx/patambanpre.html.

MASTERS, Hilary, Shadows on a wall: Juan O'Gorman and the mural in Pátzcuaro, Pittsburgh, University of Pittsburgh Press, 2005.

Monsivéis, Carlos, Las herencias ocultas de la Reforma liberal del siglo XIX, México, Debate, 1993.

, "La Malinche y el Malinchismo", La Malinche, sus padres y sus hijos, M. Glantz (ed.), México, Taurus, (1994) 2001.

ОікіÓN, Verónica, “Victoriano Anguiano Equihua (1908-1958)", en Gerardo Sánchez y Ricardo León, coords., Crecer sobre las raíces. Historiadores de Michoacán en el siglo XX, Universidad Michoacana, Morelia, 2002, 157-162.

OLCoTt, Jocelyn, Revolutionary women in postrevolutionary Mexico, Next wave, Durham, Duke University Press, 2005.

Salas LeÓn, Antonio, Pátzcuaro: cosas de antaño y hogaño, Morelia, Ed. del autor, 1968.

Santillán Aguilar, Rafael, Eréndira, Zitácuaro, Mich. [ s.n. ], 1972.

SMItH-BANNISTER, Scott, Names and naming patterns in England, 1538-1700, Oxford historical monographs, Oxford/Nueva York, Clarendon Press/Oxford University Press, 1997.

SPenser, Daniela y Bradley A. Levinson, "Linking State and Society in Discourse and Action: Political and Cultural Studies of the Cardenas Era in Mexico", Latin American Research Review, 34 (2), 1999, 227-245.

Talavera IbarRa, Pedro Leonardo y Eduardo Ruiz, Eduardo Ruiz, o, El Fausto de la Ciudad del Progreso, Morelia, Universidad Michoacana de San Nicolás de Hidalgo, Coordinación de la Investigación Científica, 1985.

PIERSON, Melissa Holbrook. Dark horses and black beauties: animals, women, a passion, Norton, Nueva York, 2000..

Ramírez Barreto, Ana Cristina, "Eréndira a caballo. Acoplamiento de cuerpos e historias en un relato de conquista y resistencia" en e-misférica. Performance and Politics in the Americas, Revista electrónica del Hemispheric Institute for Performance \& Politics (New York Univer- 
sity), 2, 2, 2005, 1-19. En línea: http:/ / www.hemisphericinstitute. org/journal/2_2/ramirez.html.

, "Eréndira on Horseback. Variations on a Tale of Conquest and Resistance", Women, ethnicity, and nationalisms in Latin America, Natividad Gutiérrez Chong (ed.), Aldershot, Hants, England, Burlington, Ashgate, 2007, 113-130.

ReEn, Ludwig, Morelia, Una Ciudad Universitaria De México, trad. Josefina Muth de Mier, Morelia, Universidad Michoacana/CECU, (1951) 1991.

ROMERo FloRes, Jesús, Diccionario michoacano de historia y geografía, Morelia, Talleres Tipográficos de la Escuela Técnica Industrial "Alvaro Obregón", 1960.

Ruzz, Eduardo, Michoacán: paisajes, tradiciones y leyendas, México, Balsal Editores (1891-1900), 1971.

_- Historia de la Guerra de Intervención en Michoacán, Morelia, Balsal, Comité Editorial del Gobierno de Michoacán, (1896) 1975.

WARREN, Benedict, "Leyenda de Eréndira. Comentario en la sesión sobre el texto 'Iconografía de Eréndira', presentado por Ana Cristina Ramírez y Mayra Gabriela Álvarez", Grupo K' waniscuyarani de estudiosos del pueblo p'urhépecha. Pátzcuaro, 30/07/ 2005.

Welton, Hattie, "La Amazona” Revista de Equitación, Secretaría de Guerra, México, 1930, 44-45.

FILMOGRAFíA

LozA, Gustavo, Al otro lado, México, Imcine / Matatena Films, 2005.

Mora CatTLEt, Juan Roberto, Eréndira Ikikunari/Eréndira, la indomable, México, Cuec/Eréndira Producciones/Foprocine/ Imcine/ Gob. Edo. Michoacán, 2007.

NAvarro, Carlos, Janitzio, México, Compañía Cinematográfica Mexicana, 1935.

FECHA DE RECEPCIÓN DEL ARTículo: 19 de marzo de 2009

FECHA DE ACEPTACIÓN Y RECEPCIÓN DE LA VERSIÓN FINAL: 17 de octubre de 2009 